\title{
Estimation of Total Quercetin and Rutin Content in Malus domestica of Nepalese Origin by HPLC Method and Determination of Their Antioxidative Activity
}

\author{
Jitendra Pandey $\mathbb{D}^{\mathrm{D}},{ }^{1,2}$ Tonking Bastola, ${ }^{2}$ Julu Tripathi, ${ }^{2}$ Milu Tripathi, ${ }^{2,3}$ \\ Rabindra Kumar Rokaya, ${ }^{2,4}$ Bhawana Dhakal, ${ }^{5}$ Rabin D. C., ${ }^{6}$ Ravin Bhandari, \\ and Amrit Poudel iD $^{2,7}$ \\ ${ }^{1}$ Department of Pharmacy, Crimson College of Technology, Affiliated to Pokhara University, Devinagar-11, Butwal 32900, Nepal \\ ${ }^{2}$ Department of Pharmacy, School of Health and Allied Science, Pokhara University, Kaski 33700, Nepal \\ ${ }^{3}$ Department of Health Service, Management Division, Health Office, Tansen, Palpa 32500, Nepal \\ ${ }^{4}$ Department of Pharmacy, Karnali Academy of Health Science, Jumla 21200, Nepal \\ ${ }^{5}$ Department of Pharmacology, Kantipur Academy of Health Science, Tinkune 44600, Kathmandu, Nepal \\ ${ }^{6}$ Department of Research and Development, Asian Pharmaceutical Private Limited, Rupandehi 32900, Nepal \\ ${ }^{7}$ Department of Biodiversity and Bioresources, Satvik Nepal, Dandakonak, Pokhara, Kaski 33700, Nepal
}

Correspondence should be addressed to Amrit Poudel; amritpoudel@gmail.com

Received 4 July 2020; Revised 3 September 2020; Accepted 5 September 2020; Published 3 November 2020

Academic Editor: Alessandro Di Cerbo

Copyright (c) 2020 Jitendra Pandey et al. This is an open access article distributed under the Creative Commons Attribution License, which permits unrestricted use, distribution, and reproduction in any medium, provided the original work is properly cited.

\begin{abstract}
Malus domestica (Apple) is one of the most widely cultivated cash crops of Nepal. Jumla and Mustang are two major pocket areas for the production of apple. Flavonoids including quercetin and rutin are potent antioxidants present in apples. This study was designed to quantify and compare the presence of quercetin and rutin in different plant parts (peel, leaf, and bark) among various cultivars of Malus domestica from two pocket zones of Nepal. A new HPLC-UV method was developed and validated for the quantification of quercetin and rutin. Polyphenols, flavonoids, and carbohydrate contents were determined by colorimetric methods. 2,2'-Diphenyl-1-picrylhydrazyl (DPPH) free radical scavenging assay was carried out to measure in vitro antioxidative activity. Acid hydrolysis of each extract was carried out by the standard method to measure aglycone quercetin content after hydrolysis of its glycosides. The total rutin content ranged from $3.69 \pm 1.34$ to $374.50 \pm 2.35 \mathrm{mg} / 100 \mathrm{~g}$ dry extract weight. Before the acidic hydrolysis, the total quercetin content ranged from $2.96 \pm 0.13$ to $171.05 \pm 0.95 \mathrm{mg} / 100 \mathrm{~g}$ dry extract weight whereas its amount increased highly after the hydrolysis and it ranged from $80.84 \pm 19.65$ to $7445.32 \pm 29.25 \mathrm{mg} / 100 \mathrm{~g}$ dry extract weight. Total polyphenol content ranged from $19.48 \pm 0.23$ to $123.48 \pm 1.84 \mu \mathrm{g}$ gallic acid equivalent/ $\mathrm{mg}$ of dry extract weight. Similarly, flavonoid content ranged from $2.21 \pm 0.72 \mu \mathrm{g}$ to $755.54 \pm 1.91 \mu \mathrm{g}$ quercetin equivalent/mg of dry extract weight. Total carbohydrate content ranged from $144.15 \pm 3.73$ to $484.65 \pm 2.63 \mu$ g glucose equivalent per $0.5 \mathrm{mg}$ dry extract weight. All the extracts showed the various degrees of antioxidant activity in a dose-dependent manner. Among them, stem bark of the Jonathan Jumla showed potent antioxidant activity with $\mathrm{IC}_{50}$ value of $13.003 \mu \mathrm{g} / \mathrm{mL}$. The present study provides the information about variation of the phytochemical content among the different cultivars, parts, and geographic locations. Furthermore, it revealed that bark of Malus domestica cultivars had high quercetin and rutin content with high antioxidant activity.
\end{abstract}

\section{Introduction}

From the prehistoric time, Malus domestica has been used as a delicious fruit [1]. Despite the great advances in modern pharmaceuticals in recent decades, nutritive plants still make an important contribution to health care. Uncontrolled production of the reactive oxygen species (ROS) leads to oxidative damage of biomolecules and results in degenerative disorders including cancer, diabetes, neuronal disorders, and aging [2]. Larger numbers of medicinal plants have 
been investigated for the antioxidant properties. Natural antioxidants are very effective to prevent oxidative stress and are believed to protect against degenerative diseases [3].

Malus domestica is a small deciduous tree (3 to 12 meters) belonging to the Rosaceae family [4]. It is widely distributed in the temperate zone throughout the world [5]. Traditionally, the infusion of the dried flower and leaves is used to control the blood pressure, fruit vinegar is given to the hearing impaired patient, and the fruit is used as diuretics, antidiarrheal, and soft laxative. Diverse class of flavonoids and polyphenols such as quercetin, rutin, quercetin-3-galactoside, catechin, epicatechin, procyanidin, cyanidin-3-galactoside, coumaric acid, chlorogenic acid, gallic acid, and phloridzin are present in apple fruit along with its leaves and bark [4]. Moreover, various biological activities such as antioxidant [6], anti-inflammatory [7], antiulcer [8], and neuroprotective effect [9] have been reported from this plant. Apple fruit is a major source of rutin, quercetin, and other flavonoids [10]. Quercetin glycosides and flavonols are present mainly in the peels whereas phenolic acids are present mainly in the fruit cortex [11]. Quercetin is mostly bounded with sugar moiety. Thus, the amount of free quercetin gets increased after acid hydrolysis [12]. The presence of quercetin and rutin in Malus domestica can be quantitatively determined by High Performance Liquid Chromatography (HPLC) [13].

The present study was designed to estimate total quercetin and rutin content in different Malus domestica of Nepalese origin by new HPLC method and evaluate their antioxidant activity along with total flavonoid, polyphenol, and carbohydrate content. The developed method is also used to compare quercetin and rutin content within different parts (peel, leaves, and stem bark) from six different cultivars.

\section{Materials and Methods}

2.1. Collection and Extraction of Plants. Fresh and healthy parts (fruit, leaves, and stem bark) of Malus domestica were collected from Marpha, Mustang (temperate region, $2650 \mathrm{~m}$ above the sea level), and Khalanga, Jumla (temperate region, $2518 \mathrm{~m}$ above the sea level), in August and September 2019. Six different cultivars were collected for the study (Table 1). The fruits were collected after maturation. The identification of plants was done by senior taxonomist Dr. Radhyashyam Kayastha and the voucher specimens were labelled and preserved at the herbarium unit of Pokhara University, Kaski, Nepal. The voucher numbers are as shown in Table 1. The fruit peels were separated by using a steel peeler. Seeds were removed from the pulp manually. All the plant materials were cut into $1 \times 1 \mathrm{~cm}$ slices. All the sliced plant materials were spread over the clean filter paper and placed in the laboratory having a well-ventilated room at $25^{\circ} \mathrm{C}$ for 15 days. Plant materials were constantly turned to prevent the possible fungal growth. After the plant parts were dried, they were ground to a fine powder using a portable grinding machine. The reduced powder mass was then passed through the sieve of mesh size 40 . The dried slice of the pulp was extracted without grinding due to its sticky nature.
Triple cold maceration technique was adopted for the extraction process in which $100 \mathrm{~g}$ of each sample was soaked with $1000 \mathrm{~mL}$ methanol using conical flasks with occasional shaking for 24 hours; then liquids were strained and the marcs were pressed. The strained liquids were then subjected to filtration. The operation was repeated up to three times and filtrate was mixed. The filtrate obtained was dried by using a rotary vacuum evaporator at $40^{\circ} \mathrm{C}$ to get viscous concentrate which was further dried by using a vacuum desiccator and so obtained extract was stored at $4^{\circ} \mathrm{C}$ until use.

2.2. Phytochemical Screening. All the plant extracts were screened for the presence of alkaloid, saponin, terpenoid, anthraquinone, tannin, cardiac glycosides, flavonoid, carbohydrate, polyphenols, protein, amino acid, resin, and phytosterol according to previously established method [14-16].

2.3. Estimation of Total Phenolic Content. Total phenolic content (TPC) was determined by Folin-Ciocalteu (FC) method with slight modification [17]. In this analysis, $1 \mathrm{~mL}$ of the sample $(1 \mathrm{mg} / \mathrm{mL})$ was mixed with $1 \mathrm{~mL}$ of the $2 \mathrm{~N} \mathrm{FC}$ reagent followed by the addition of $5 \mathrm{~mL}$ distilled water and mixed thoroughly. After $5 \mathrm{~min}, 1 \mathrm{~mL}$ of the $10 \% \mathrm{Na}_{2} \mathrm{CO}_{3}$ was added to the mixture and incubated at room temperature for 1 hour. Finally, the absorbance of the reaction mixture was measured at $725 \mathrm{~nm}$ against a blank. The estimation of the phenolic compound was carried out in triplicate. The TPC was expressed as $\mu \mathrm{g}$ gallic acid equivalent (GAE)/mg of dry extracts using the calibration curve of gallic acid.

2.4. Estimation of Total Flavonoid Content. Total flavonoid content (TFC) was determined by adopting an established method with slight modification [18]. $1 \mathrm{~mL}$ of the sample $(1 \mathrm{mg} / \mathrm{mL})$ was mixed with $4 \mathrm{~mL}$ of the distilled water and $0.3 \mathrm{~mL}$ of the $5 \% \mathrm{NaNO}_{2}$. After $5 \mathrm{~min}, 0.3 \mathrm{~mL}$ of the $10 \%$ $\mathrm{AlCl}_{3}$ was added and then incubated for $5 \mathrm{~min}$. Then $2 \mathrm{~mL}$ of the $1 \mathrm{M} \mathrm{NaOH}$ was added and the solution was mixed well. After $30 \mathrm{~min}$, the absorbance was measured against the blank solution at $510 \mathrm{~nm}$. The estimation of the flavonoid compound was carried out in triplicate. TFC was expressed as $\mu \mathrm{g}$ of quercetin equivalents (QE/mg) of dry extracts, using calibration curve of quercetin.

2.5. Estimation of Total Carbohydrate Content. The total carbohydrate was determined by the phenol-sulphuric acid method [19]. In a $10 \mathrm{~mL}$ of test tube, $1 \mathrm{~mL}$ of the sample $(1 \mathrm{mg} / \mathrm{mL}), 1 \mathrm{~mL}$ of the $5 \%$ phenol solution and $5 \mathrm{~mL}$ of the concentrated sulphuric acid were mixed properly. After $10 \mathrm{~min}$, the contents of the tube were mixed and placed in a water bath set at $25-30^{\circ} \mathrm{C}$ for $20 \mathrm{~min}$ and the absorbance was measured against the blank at $490 \mathrm{~nm}$. The standard curve for total carbohydrate content was made using a glucose standard solution. Total carbohydrate content was expressed as $\mu \mathrm{g}$ of glucose equivalents per $0.5 \mathrm{mg}$ of dry extracts. 
TABLE 1: Plant extract of six distinct apple cultivars and corresponding extractive yield of methanol extract.

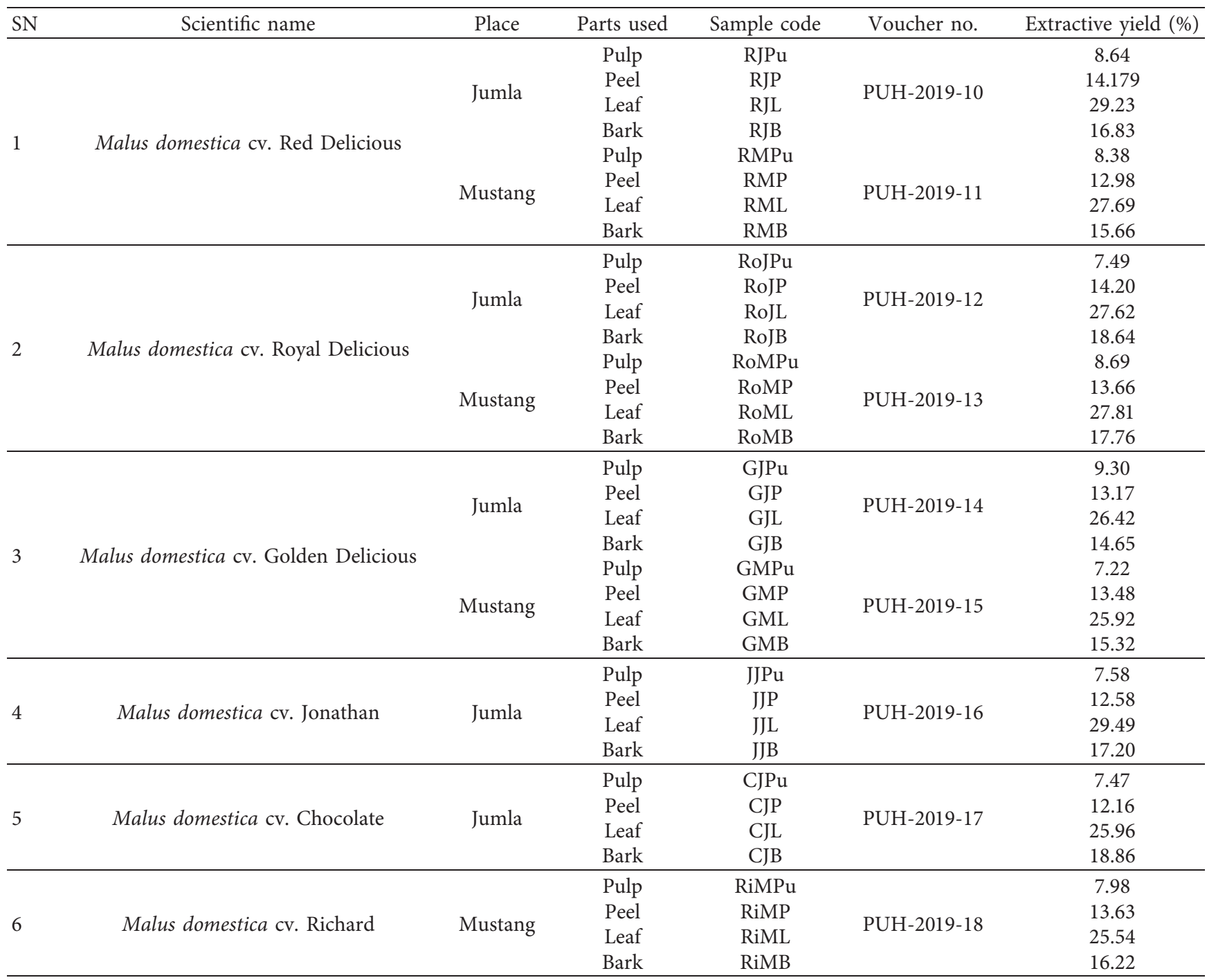

2.6. DPPH Radical Scavenging Activity. The antioxidant capacity of peel, leaves, and stem bark samples from all the cultivars was confirmed by $2,2^{\prime}$-diphenyl-1-picrylhydrazyl (DPPH) free radical scavenging activity assay according to established method with slight modification [20,21]. DPPH solution was prepared in methanol at a concentration of $0.1 \mathrm{mM}$. Five different concentrations of plant extracts were prepared by serial dilution $(250-15.625 \mu \mathrm{g} / \mathrm{mL}) .2 \mathrm{~mL}$ of each test sample and $2 \mathrm{~mL}$ of prepared DPPH solution were mixed with vigorous shaking and kept in dark at room temperature. After $15 \mathrm{~min}$, absorbance was measured at $517 \mathrm{~nm}$ by using a UV spectrophotometer. Methanol and ascorbic acid were used as negative and positive controls, respectively. The entire test was performed in triplicate. The percentage of radical scavenging was calculated using the following formula.

$$
\text { percentage of radical scavenging }=\left[\frac{A_{0}-A_{1}}{A_{0}}\right] * 100 \text {, }
$$

where $A_{0}$ was the absorbance of DPPH solution and $A_{1}$ was the absorbance of the sample.
2.7. Optimization of the HPLC Method for Analysis. Quantitative analysis of quercetin and rutin in different samples was done using an HPLC system of LC2010CHT (Shimadzu, Japan), lab-solution software, UV-Visible detector set at $374 \mathrm{~nm}$, and autosampler set at $10 \mu \mathrm{L}$ injection. All chromatographic analysis was performed at $40^{\circ} \mathrm{C}$ on the C18 column (J Sphere ODS-L80, 5-4 $\mu \mathrm{m}, 4.6 * 150$ ) and a flow rate of $1 \mathrm{~mL} / \mathrm{min}$. The mobile phase consisted of methanol (A) and $100 \mathrm{mM}$ sodium dihydrogen phosphate buffer with $\mathrm{P}^{\mathrm{H}} 2.1$ (B) with gradient elution for better separation. The gradient solvent system was optimized as $5 \%$ A (0-5 min), $5-10 \%$ A (5-10 min), $10 \%$ A (10-15 min), $10-15 \%$ A (15-20 min), 15\% A (20-25 min), $15-20 \%$ A (25-30 min), 20\% A (30-35 min), 20-22\% A (35-40 min), $22 \%$ A (40-45 min), 22-25\% A (45-50 min), 25\% A (50-55 min), $\quad 25-30 \% \quad$ A $\quad(55-60 \mathrm{~min}), \quad 30-35 \% \quad \mathrm{~A}$ (60-65 $\mathrm{min})$, and $35-50 \% \mathrm{~A}(65-70 \mathrm{~min})$.

2.7.1. Preparation of Standard and Sample Solution. The stock solutions of quercetin and rutin were prepared in 
methanol at the concentration of $2 \mathrm{mg} / \mathrm{mL}$. Both stock solutions were diluted serially as necessary to plot the calibration curve. The sample solutions of peel $(200 \mathrm{mg} / \mathrm{mL})$, leaf, and stem bark extracts $(50 \mathrm{mg} / \mathrm{mL})$ of $M$. domestica were prepared in HPLC grade methanol using an ultrasonic water bath at a temperature of $40^{\circ} \mathrm{C}$. All the sample solutions were filtered with the help of $0.20 \mu \mathrm{m}$ filters (PTFE filters, Thermo Scientific, Waltham, MA, USA) before injection.

2.7.2. Acid Hydrolysis of Extract. Hydrolysis of peel, leaves, and stem bark extract was carried out by using $1.5 \mathrm{M} \mathrm{HCl}$ $[12,22]$. Five $\mathrm{mL}$ of methanolic peel $(400 \mathrm{mg} / \mathrm{mL})$, leaf, and stem bark $(100 \mathrm{mg} / \mathrm{mL})$ extract solution was placed in airtight tube followed by the addition of $3 \mathrm{M} \mathrm{HCl}(5 \mathrm{~mL})$. The tubes were then heated at $60^{\circ} \mathrm{C}$ in a water bath with continuous shaking. The acid hydrolysis was carried out for different time intervals ( $30 \mathrm{~min}, 45 \mathrm{~min}$, and 1 hour). After hydrolysis, samples were centrifuged. The filtrate so obtained was injected in HPLC for analysis of peak area.

2.7.3. Method Validation. The method was validated for linearity, limit of detection and quantification (LOD and LOQ), precision (intraday and interday variation and repeatability), and accuracy (recovery) following ICH guideline [23] and some report in literature [24].

2.7.4. Quantification of Quercetin and Rutin from M. domestica Extracts. The validated analytical method was used to determine total quercetin and rutin content simultaneously in different samples. The quantification of quercetin and rutin before and after the acid hydrolysis of all the extract was done by linear regression of the standards. All the samples were analyzed in triplicate to determine the average content. The content of quercetin and rutin in sample extract was expressed as $\mathrm{mg} / 100 \mathrm{~g}$ of dry extract.

2.8. Statistical Analysis. All the tests were done in triplicate and the data were expressed as mean \pm SD. Statistical significance of differences was determined using a one-way analysis of variance (One-way ANOVA), with Tukey post hoc test using GraphPad Prism 6.0 software. A $P$-value < 0.05 was considered significant.

\section{Results}

3.1. Phytochemical Screening. Phytochemical screening of different samples of $M$. domestica showed the presence of varied degree of alkaloid, saponin, terpenoid, anthraquinones, tannin, cardiac glycoside, flavonoid, carbohydrate, polyphenol, protein and amino acid, resin, and phytosterol. The results are summarized in Table 2.

3.2. Total Phenolic Content (TPC). The quantitative determination of total phenol was carried out using Folin-Ciocalteu reagent with the help of gallic acid calibration curve and was expressed as $\mu \mathrm{g}$ of gallic acid equivalent per milligram dry extract weight, which revealed that the highest TPC was shown by Jonathan stem bark Jumla $(123.48 \pm 1.84 \mu \mathrm{g})$ whereas peel extract of Golden Jumla revealed the lowest value $(19.48 \pm 0.23 \mu \mathrm{g})$. Figure 1 shows the comparison of TPC of different extract of Malus domestica. Analysis of variance (ANOVA) indicated that the total phenol content of apple bark extracts was significantly higher than peel and leaf extracts. Between peel and leaf, leaf contained significantly higher amount of polyphenol. Among the varieties, bark extract of Jonathan cultivar contained significantly higher amount of polyphenol than other varieties.

3.3. Total Flavonoid Content (TFC). The TFC of plant extracts was expressed as $\mu \mathrm{g}$ of quercetin equivalent per milligram dry extract weight (Figure 2). The value ranged from 2.21 to $755.54 \mu \mathrm{g} \mathrm{QE} / \mathrm{mg}$ of dry extract. The stem bark of the Chocolate Jumla was found to contain the highest flavonoid whereas the lowest TFC was reported in Golden peel Jumla. Analysis of variance (ANOVA) indicated that the total flavonoid content of apple bark extracts was significantly higher than peel and leaf extracts. Between peel and leaf, leaf contained significantly higher amount of flavonoids. Among the varieties, bark extract of Chocolate cultivar contained significantly higher amount of flavonoid than other varieties.

3.4. Total Carbohydrate Content (TCC). To investigate the variation in nutritional value among the apple fruits of different cultivars at two different regions, the total carbohydrate content was calculated using phenol-sulphuric method in terms of glucose equivalent. As shown in Figure 3, the highest carbohydrate content was detected in Royal pulp Mustang ( $484.649 \pm 2.631 \mu \mathrm{g}$ glucose $/ 0.5 \mathrm{mg}$ dry extract) and Golden pulp Jumla had shown lowest carbohydrate content (393.97 $\pm 0.68 \mu \mathrm{g}$ glucose $/ 0.5 \mathrm{mg}$ dry extract). Analysis of variance (ANOVA) indicated that the total carbohydrate content of apple pulp extracts was significantly higher than peel, leaf, and bark extracts. Between bark and leaf; bark contained significantly higher amount of carbohydrate within the same cultivar.

3.5. Antioxidant Activity. Among 27 different extracts of M. domestica, stem bark extracts of Jonathan Jumla showed strong antioxidant activity $\left(\mathrm{IC}_{50}: 13.01 \mu \mathrm{g} / \mathrm{mL}\right)$ as determined by DPPH radical scavenging assay method whereas lowest antioxidant activity $\left(\mathrm{IC}_{50}: 242.34 \mu \mathrm{g} / \mathrm{mL}\right.$ ) was shown by fruit peel extract of the same plant. $\mathrm{IC}_{50}$ value of all the extract is depicted in Table 3. Similarly, Figures 4 and 5 represent the DPPH radical scavenging potency of different parts of M. domestica from Jumla and Mustang, respectively.

3.6. Optimization of Chromatographic Conditions. The HPLC conditions were investigated for the mobile phase and detection wavelength for better chromatographic resolution. To obtain accurate valid and optimal chromatographic conditions, various mobile phases (methanol-water and acetonitrile-water with different modifiers including glacial 
TABLe 2: Phytochemical screening of pulp, peel, leaf, and stem bark of different $M$. domestica cultivars from two regions of Nepal.

\begin{tabular}{|c|c|c|c|c|c|c|c|c|c|}
\hline $\begin{array}{l}\text { S.N. } \\
\text { Pulp }\end{array}$ & Test & RJ & RoJ & GJ & $\mathrm{JJ}$ & $\mathrm{CJ}$ & $\mathrm{RM}$ & RoM & GM \\
\hline (1) & Alkaloid & - & - & - & - & - & - & - & - \\
\hline (2) & Saponin & + & + & ++ & ++ & +++ & ++ & + & ++ \\
\hline (3) & Terpenoid & +++ & ++ & +++ & +++ & ++ & +++ & +++ & +++ \\
\hline (4) & Anthraquinone & + & + & ++ & + & ++ & + & + & + \\
\hline (5) & Tannin & ++ & + & ++ & + & + & ++ & + & + \\
\hline (6) & Cardiac glycosides & ++ & ++ & +++ & ++ & +++ & ++ & ++ & +++ \\
\hline (7) & Flavonoid & - & - & - & - & - & - & - & - \\
\hline (8) & Carbohydrate & +++ & +++ & ++ & +++ & +++ & +++ & +++ & +++ \\
\hline (9) & Polyphenol & + & + & + & + & + & + & + & + \\
\hline (10) & Protein and amino acid & +++ & ++ & +++ & +++ & ++ & +++ & +++ & ++ \\
\hline$(11)$ & Resin & - & - & - & - & - & - & - & - \\
\hline (12) & Phytosterol & +++ & ++ & +++ & +++ & +++ & +++ & ++ & +++ \\
\hline
\end{tabular}

\section{Peel}

\section{Alkaloid \\ Saponin \\ Terpenoid \\ Anthraquinone \\ Tannin \\ Cardiac glycosides \\ Flavonoid \\ Carbohydrate \\ Polyphenol}

Protein and amino acid

Resin

Phytosterol

\section{Leaf}

(1)

(2)

(3)

(4)

(5)

(6)

(7)

(8)

(9)

(11)

(12)

Stem bark

(1)

(2)

(3)

(4)

(5)

(6)

(7)

(8)

(11)

Alkaloid
Saponin
Terpenoid
Anthraquinone
Tannin
Cardiac glycosides
Flavonoid
Carbohydrate
Polyphenol
Protein and amino acid
Resin
Phytosterol

Alkaloid

Saponin

Terpenoid

Anthraquinone

Tannin

Cardiac glycosides

Flavonoid

Carbohydrate

Polyphenol

Protein and amino acid Resin

Phytosterol

Phytosterol

$\begin{array}{ccr}- & - & - \\ ++ & +++ & ++ \\ ++ & +++ & ++ \\ ++ & ++ & + \\ +++ & +++ & ++ \\ + & +++ & +++ \\ + & + & + \\ +++ & +++ & + \\ + & + & + \\ ++ & +++ & ++ \\ + & ++ & + \\ ++ & +++ & ++\end{array}$

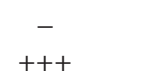

$\begin{array}{cccc}- & - & - & - \\ ++ & ++ & +++ & +++ \\ +++ & +++ & ++ & +++ \\ ++ & ++ & + & ++ \\ +++ & +++ & ++ & ++ \\ +++ & ++ & ++ & +++ \\ + & + & + & + \\ ++ & +++ & ++ & +++ \\ ++ & ++ & + & ++ \\ ++ & ++ & ++ & +++ \\ +++ & + & + & ++ \\ +++ & +++ & ++ & +++\end{array}$

$\begin{array}{ccc}+++ & ++ & ++ \\ +++ & +++ & +++ \\ ++ & ++ & ++ \\ ++ & +++ & +++ \\ ++ & +++ & ++ \\ + & + & + \\ ++ & ++ & +++ \\ + & ++ & ++ \\ +++ & ++ & ++ \\ + & +++ & + \\ +++ & +++ & +++\end{array}$

$+$

$\begin{array}{cccc}+ & ++ & ++ & + \\ +++ & +++ & +++ & +++ \\ +++ & ++ & ++ & ++ \\ - & - & - & - \\ +++ & +++ & +++ & ++ \\ - & - & - & - \\ ++ & ++ & ++ & ++ \\ + & + & + & ++ \\ ++ & ++ & +++ & ++ \\ - & - & - & - \\ +++ & +++ & ++ & +++ \\ +++ & ++ & ++ & +++\end{array}$

$\begin{array}{lllll}++ & \text { + } & & +++\end{array}$

\begin{tabular}{cccccc}
++ & +++ & +++ & ++ & +++ & +++ \\
++ & +++ & ++ & ++ & +++ & +++ \\
+++ & +++ & +++ & +++ & +++ & +++ \\
+ & + & +++ & ++ & ++ & ++ \\
- & - & - & - & - & - \\
- & - & - & - & - & - \\
+++ & +++ & ++ & ++ & +++ & ++ \\
+++ & + & +++ & + & ++ & ++ \\
+++ & +++ & ++ & + & ++ & ++ \\
- & - & - & - & - & - \\
++ & + & + & + & + & + \\
+++ & ++ & +++ & +++ & ++ & ++ \\
\hline
\end{tabular}
Chocolate Jumla, GJ: Golden Jumla, RM: Red Delicious Mustang, RoM: Royal Delicious Mustang, GM: Golden Mustang, and RiM: Richard Mustang.

acetic acid and phosphoric acid) with different analysis time were examined. The optimized gradient solvent system consists of methanol/sodium dihydrogen phosphate buffer with $\mathrm{P}^{\mathrm{H}} 2.1$ in the water at column temperature $40^{\circ} \mathrm{C}$ with a flow rate of $1 \mathrm{~mL} / \mathrm{min}$. The analysis time was optimized with $70 \mathrm{~min}$. The choice of $374 \mathrm{~nm}$ as wavelength enabled a high absorbance of both standards. Figure 6 represents the chromatogram of a standard mixture of quercetin and rutin. 


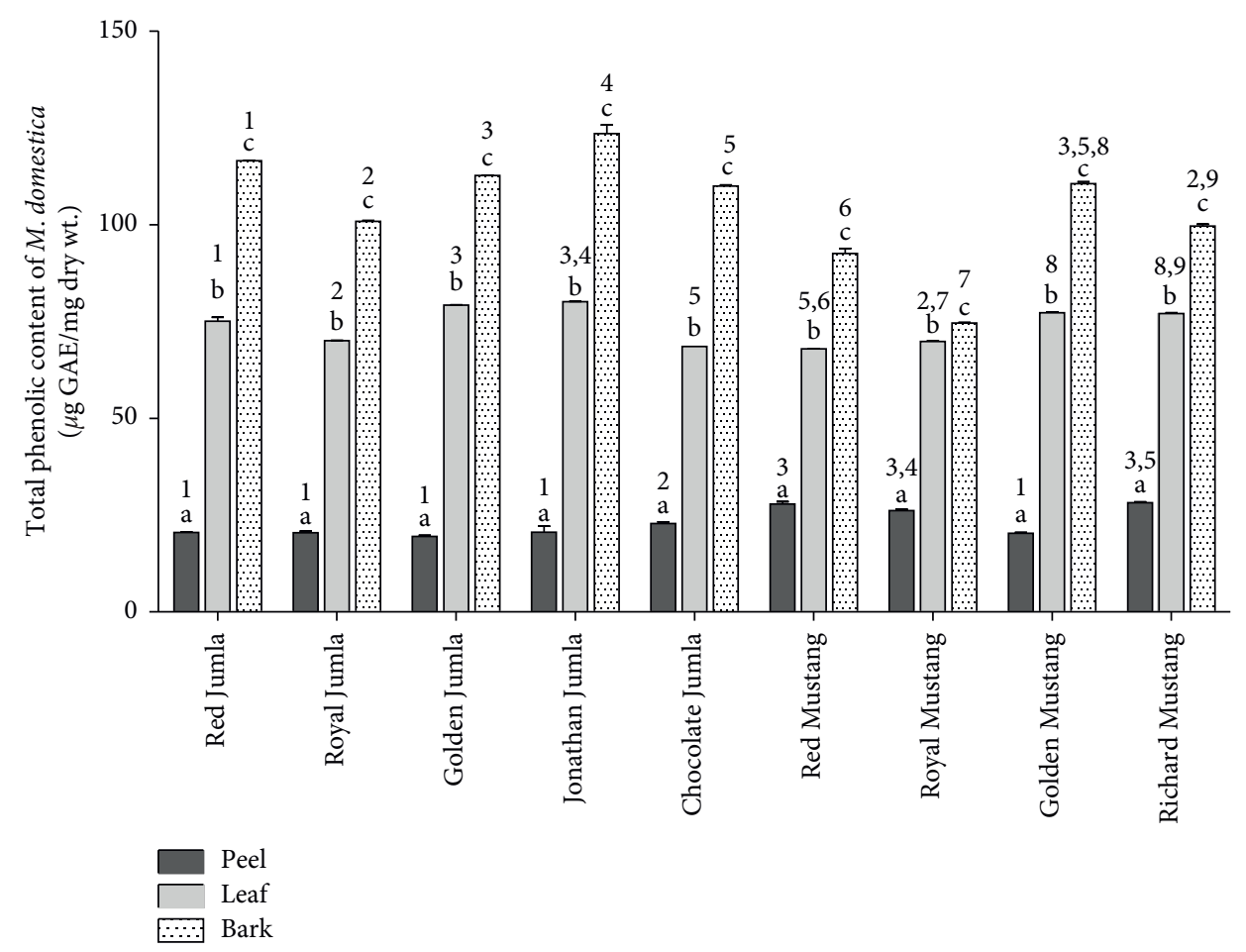

FIgUre 1: Total phenol content of methanolic extract of peel, leaf, and stem bark in different $M$. domestica cultivars from two different regions of Nepal. Different letters $(\mathrm{a}-\mathrm{c})$ on bars indicate significant differences $(P<0.05)$ between peel, leaf, and bark within the same cultivar. Different numbers (1-9) on bars indicate significant differences $(P<0.05)$ among the cultivars for same plant parts (peel, leaf, or bark).

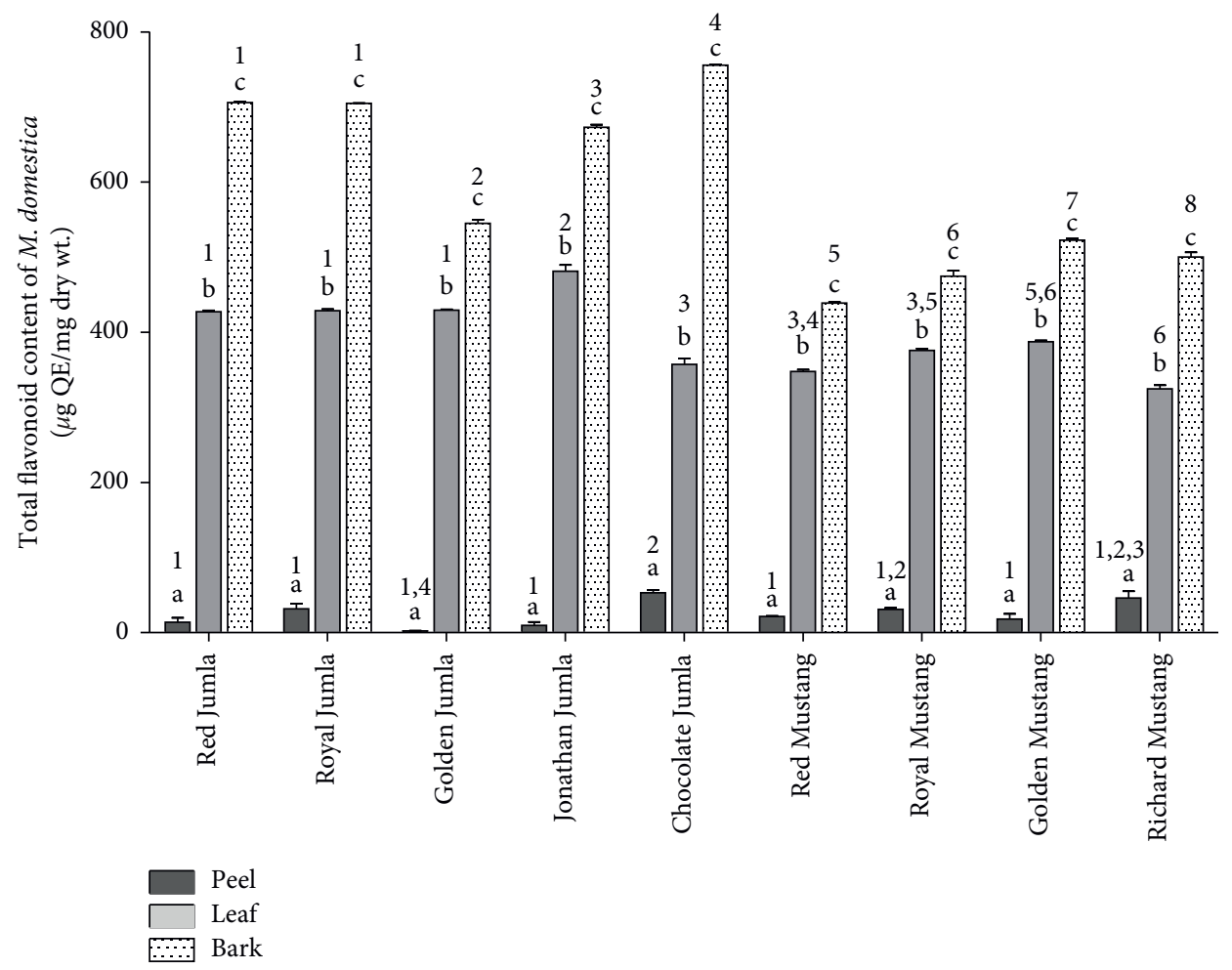

Figure 2: Total flavonoid content of methanolic extract of peel, leaf, and stem bark in different $M$. domestica cultivars from two different regions of Nepal. Different letters $(\mathrm{a}-\mathrm{c})$ on bars indicate significant differences $(P<0.05)$ between peel, leaf, and bark within the same cultivar. Different numbers $(1-8)$ on bars indicate significant differences $(P<0.05)$ among the cultivars for same plant parts (peel, leaf, or bark). 


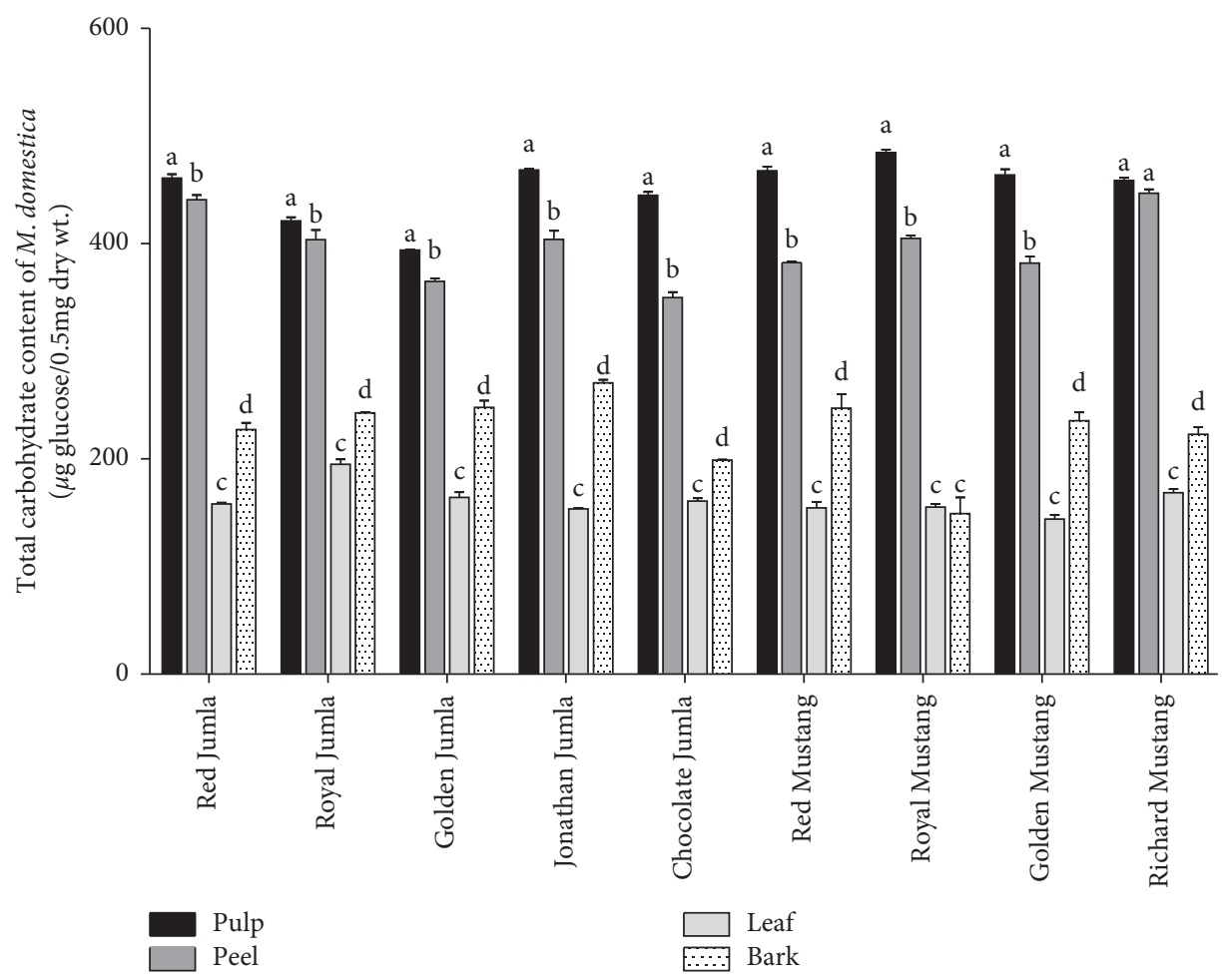

Figure 3: Total carbohydrate content of methanolic extract of pulp, peel, leaf, and stem bark in different $M$. domestica cultivars from two different regions of Nepal. Different letters $(\mathrm{a}-\mathrm{d})$ on bars indicate significant differences $(P<0.05)$ between pulp, peel, leaf, and bark within the same cultivar.

TABLE 3: $\mathrm{IC}_{50}$ values of peel, leaf, and stem bark of different $M$. domestica cultivars from two different regions of Nepal along with ascorbic acid.

\begin{tabular}{|c|c|c|c|c|}
\hline Sample & Peel $(\mu \mathrm{g} / \mathrm{mL})$ & Leaf $(\mu \mathrm{g} / \mathrm{mL})$ & Stem bark $(\mu \mathrm{g} / \mathrm{mL})$ & Ascorbic acid $(\mu \mathrm{g} / \mathrm{mL})$ \\
\hline Red (J) & 89.63 & 15.49 & 16.19 & \\
\hline Royal (J) & 139.19 & 24.64 & 18.01 & \\
\hline Golden (J) & 177.32 & 30.84 & 18.08 & \\
\hline Jonathan (J) & 242.34 & 22.22 & 13.01 & \\
\hline Chocolate (J) & 85.06 & 38.84 & 14.60 & 3.51 \\
\hline $\operatorname{Red}(\mathrm{M})$ & 62.52 & 39.62 & 22.44 & \\
\hline Royal (M) & 97.62 & 26.55 & 30.55 & \\
\hline Golden (M) & 177.62 & 24.24 & 20.58 & \\
\hline Richard (M) & 94.68 & 27.06 & 20.52 & \\
\hline
\end{tabular}

Similarly, chromatogram of peel, leaf, and stem bark extract is shown in Figure 7.

3.7. Method Validation. Chromatographic investigation for linearity, precision, and accuracy was conducted to ensure the selectivity, preciseness, and reproducibility of the optimized technique. For the linearity, seven different concentrations $(7.8125-500 \mu \mathrm{g} / \mathrm{mL})$ for rutin and quercetin were injected separately. Calibration curve equations were obtained by plotting peak area versus concentration. Since the correlation coefficient $\left(R^{2}\right)$ of both standards was 0.9999 and 0.9996 , linearity was verified. Detail information regarding the calibration curve, linear range, LOD, and LOQ is listed in Table 4.

The precision of the optimized analytical method was verified by interday and intraday variation together with the repeatability of sixtuplets. The RSD of intraday and interday analysis were reported to be in the range of $0.16-0.71 \%$ and $0.14-0.97 \%$, respectively (Table 5 ).

The repeatability of quercetin and rutin was evaluated by injecting standard mixture six times in the same day. The RSD was found to be 0.72 and $1.48 \%$ for quercetin and rutin, respectively (Table 6).

The accuracy was measured by determining the recovery of the spiked standard to the extract. The three different concentrations (low, medium, and high) of the standard were added to the known sample. The percentage of recovery and RSD were calculated, which showed a recovery of $96.67-102.89 \%$ and RSD of $0.03-0.53 \%$ (Table 7 ).

3.8. Quantitative Determination of Quercetin and Rutin in M. domestica Sample. Peel, leaf, and stem bark extracts of six 


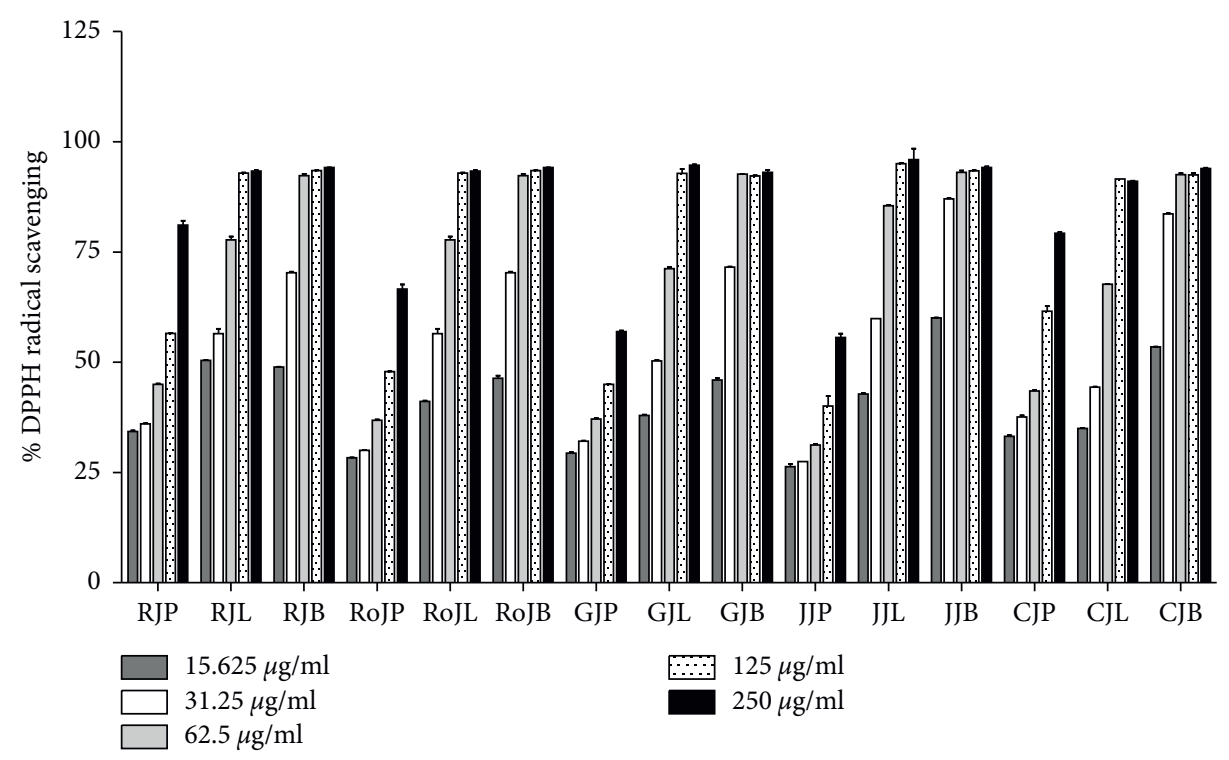

FIGURE 4: Bar diagram showing DPPH free radical scavenging capacities of peel, leaf, and stem bark extract of five different $M$. domestica cultivars from Jumla.

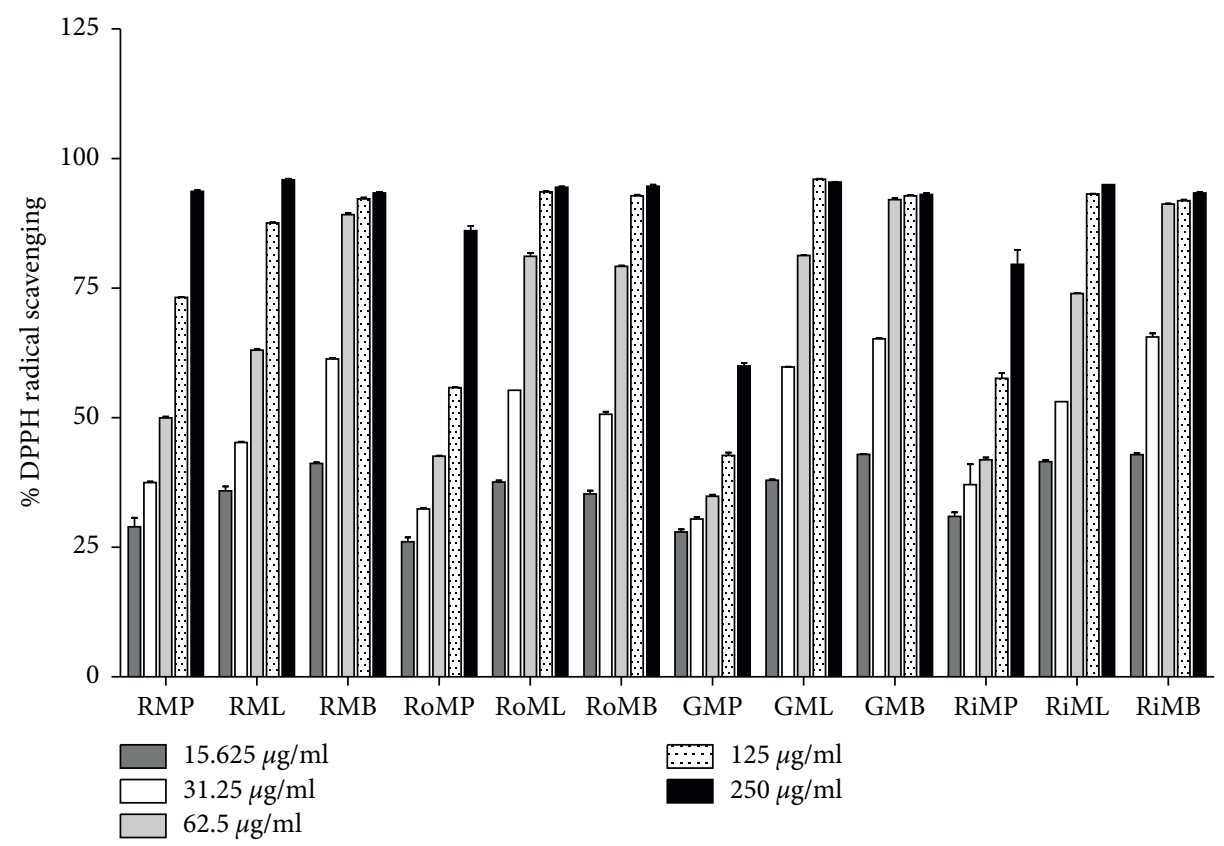

Figure 5: Bar diagram showing DPPH free radical scavenging capacities of peel, leaf and stem bark extract of four different $M$. domestica cultivars from Mustang.

different $M$. domestica cultivars from two different regions of Nepal were quantitatively examined for the amount of quercetin and rutin with the help of the newly optimized validated method (Table 8). Total quercetin and rutin contents were expressed as mg per $100 \mathrm{~g}$ dry extract. The stem bark extract of Chocolate Jumla was reported to contain $171.05 \mathrm{mg} / 100 \mathrm{~g}$ of quercetin while peel extract of Richard Mustang was reported to contain $2.66 \mathrm{mg} / 100 \mathrm{~g}$ of quercetin. Similarly, the stem bark extract of Jonathan Jumla exhibited the highest amount $(374.5 \mathrm{mg} / 100 \mathrm{~g})$ of rutin whereas lowest rutin content was detected in the peel extract of Richard Mustang $(3.59 \mathrm{mg} / 100 \mathrm{~g})$. As shown in Table 8, there was some variation among the extracts of same cultivar (Red Delicious, Royal Delicious, and Golden) collected from the different locations. In case of fruits, the content of quercetin and rutin was comparatively higher from Mustang. Oppositely, the content of both compounds from the Mustang sample was relatively low as compared to Jumla in case of leaf and bark extract. Furthermore, leaf and bark extract of $M$. domestica showed comparatively higher 


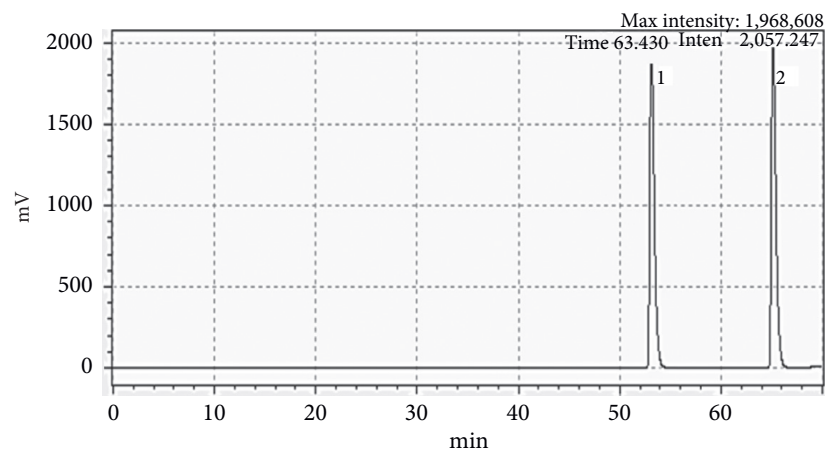

Figure 6: Chromatogram of standard mixture (1: rutin; 2: quercetin).

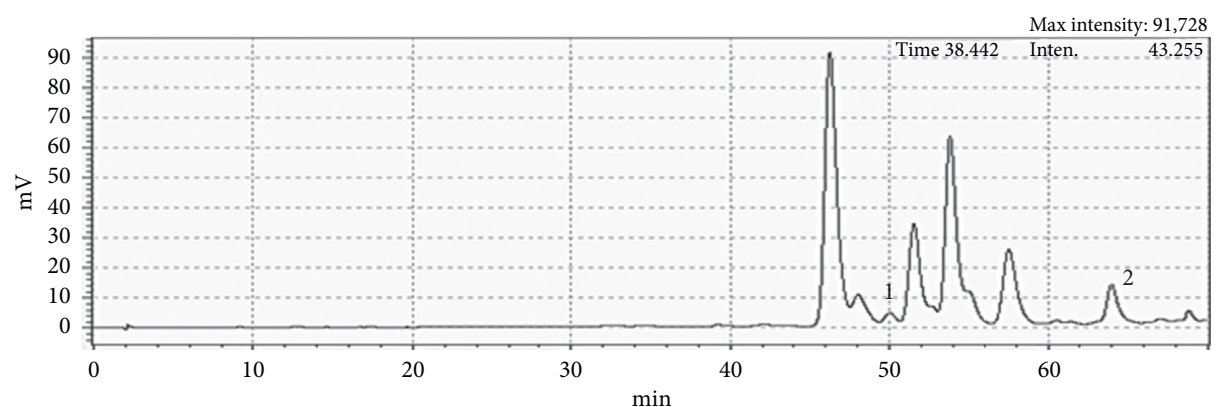

(a)

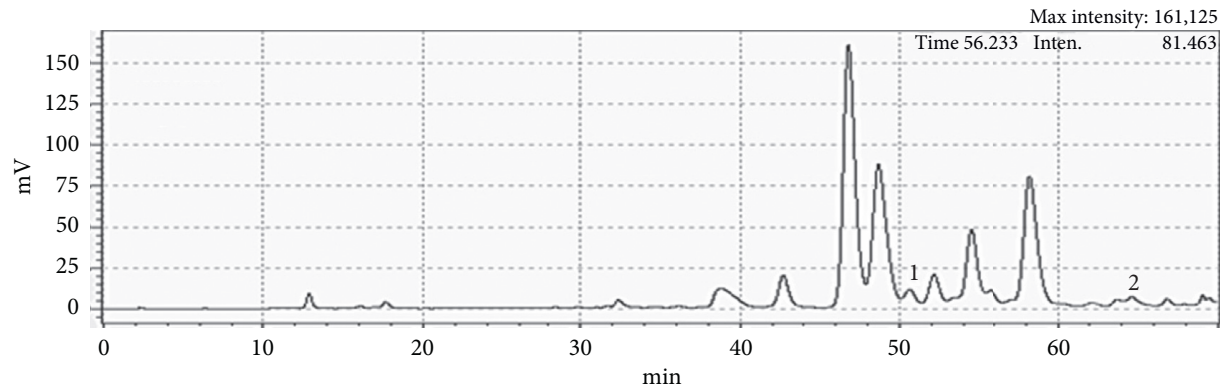

(b)

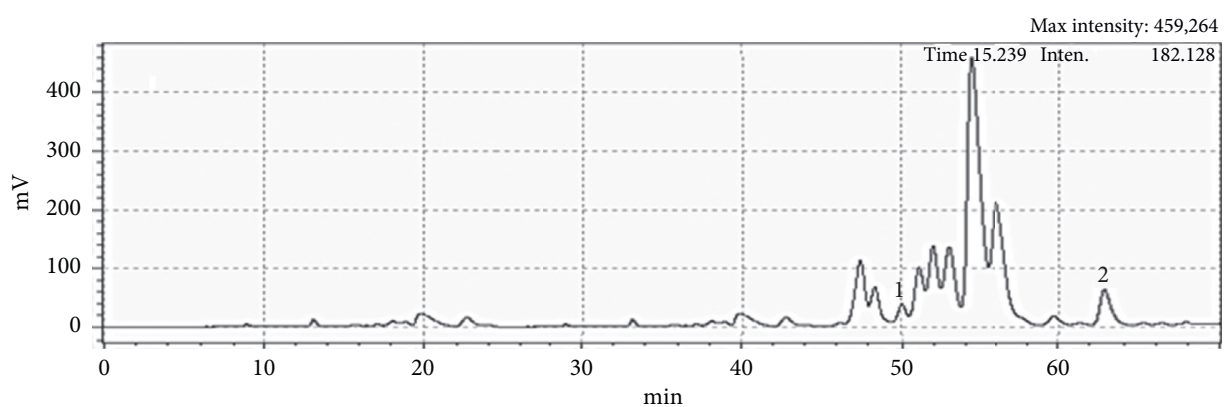

(c)

Figure 7: Chromatogram of different $M$. domestica sample at $374 \mathrm{~nm}$ (a) peel, (b) leaf, and (c) stem bark; 1: rutin and 2: quercetin.

quercetin and rutin content than peel. Analysis of variance (ANOVA) indicated that the total rutin and quercetin content of apple bark extracts was significantly higher than peel and leaf extracts within the same cultivar. Between peel and leaf, leaf contained significantly higher amount of rutin and quercetin. Among the varieties, bark extract of Jonathan cultivar contained significantly higher amount of rutin and bark of Royal Jumla cultivar contained significantly higher amount of quercetin than other varieties.

Acid hydrolysis was optimized for $45 \mathrm{~min}$ which increased the total amount of quercetin in peel, leaf, and steam bark extracts. Hydrolysis of the sample also led to the 
TABLE 4: Regression data, LODs, and LOQs for quercetin and rutin analyzed by HPLC.

\begin{tabular}{lcccc}
\hline Standards & Regression equation & $R^{2}$ & LOD $(\mu \mathrm{g} / \mathrm{mL})$ & LOQ $(\mu \mathrm{g} / \mathrm{mL})$ \\
\hline Quercetin & $y=34751 x+40572$ & 0.9999 & 0.379 & 1.148 \\
Rutin & $y=9766.4 x+19679$ & 0.9996 & 0.641 & 1.946 \\
\hline
\end{tabular}

Note. All the tests were done in triplicate; $y=$ peak area; $x$ : concentration $(\mu \mathrm{g} / \mathrm{mL})$.

TABLe 5: Analytical results of intraday and interday variability.

\begin{tabular}{|c|c|c|c|c|c|}
\hline \multirow{2}{*}{ Standard } & \multirow{2}{*}{ Concentration $(\mu \mathrm{g} / \mathrm{mL})$} & \multicolumn{2}{|c|}{ Intraday } & \multicolumn{2}{|c|}{ Interday } \\
\hline & & Mean \pm SD & RSD (\%) & Mean \pm SD & RSD (\%) \\
\hline \multirow{3}{*}{ Quercetin } & 250 & $251.42 \pm 1.15$ & 0.46 & $248.81 \pm 0.34$ & 0.14 \\
\hline & 125 & $125.43 \pm 0.41$ & 0.33 & $124.64 \pm 1.21$ & 0.97 \\
\hline & 62.5 & $62.14 \pm 0.29$ & 0.47 & $63.20 \pm 0.54$ & 0.85 \\
\hline \multirow{3}{*}{ Rutin } & 250 & $252.51 \pm 0.41$ & 0.16 & $252.69 \pm 1.25$ & 0.49 \\
\hline & 125 & $126.21 \pm 0.89$ & 0.71 & $125.05 \pm 0.63$ & 0.5 \\
\hline & 62.5 & $62.06 \pm 0.31$ & 0.49 & $61.22 \pm 0.44$ & 0.72 \\
\hline
\end{tabular}

Note. All the tests were done in triplicate.

TABLE 6: Repeatability of standard quercetin and rutin.

\begin{tabular}{lcccc}
\hline Standard & $\begin{array}{c}\text { Amount } \pm \mathrm{SD}(\mu \mathrm{g} / \\
\mathrm{ml})\end{array}$ & $\begin{array}{c}\mathrm{RSD} \\
(\%)\end{array}$ & $\begin{array}{c}T_{\mathrm{r}} \\
(\mathrm{min}) \pm \mathrm{SD}\end{array}$ & $\begin{array}{c}\mathrm{RSD} \\
(\%)\end{array}$ \\
\hline Quercetin & $78.30 \pm 0.56$ & 0.72 & $63.57 \pm 0.06$ & 0.090 \\
Rutin & $107.54 \pm 1.60$ & 1.48 & $50.90 \pm 0.02$ & 0.03 \\
\hline
\end{tabular}

Note. All the tests were done in triplicate.

conversion of rutin into free quercetin form. As shown in Table 9, the total content of quercetin was found to be highest in Royal bark Jumla (7445.32 mg/100 g dry extract) and the lowest quercetin was reported in the peel extract of Richard Jumla $(80.84 \mathrm{mg} / 100 \mathrm{~g}$ dry extract). Analysis of variance (ANOVA) indicated that after acid hydrolysis also the quercetin content of apple bark extracts was significantly higher than peel and leaf extracts within the same cultivar. Between peel and leaf, leaf contained significantly higher amount of quercetin. Among the varieties, bark of Royal Jumla cultivar contained significantly higher amount of quercetin than other varieties.

\section{Discussion}

Preliminary investigation of phytochemicals is a crucial step for identifying various pharmacologically effective secondary metabolites of plants exhibiting a vital role towards the advantageous medicinal and physiological properties such as antioxidant, antidiabetic, anticarcinogenic, and antimicrobial activities [25]. The phytochemical screening proclaimed the presence of polyphenol, saponins, terpenoid, flavonoid, and phytosterol in the methanolic extract of all samples. In this study, alkaloids were present only in leaf and stem bark extract. Protein, amino acid, and cardiac glycosides were present only in pulp and peel extract. Resins were not present in the pulp, anthraquinones were not present in leaf, and tannins were not present in the bark.

Phenolic compounds are the major phytochemical constituents of plants to exhibit the antioxidant action and various therapeutic activities such as cardiovascular protective, antiatheroscleretic, anti-inflammatory, anticarcinogenesis, and antiaging, due to the scavenging capacity of their hydroxyl group [26]. The phenolic compounds such as flavonoids and phenolic acid are attributed to the antioxidant activity of $M$. domestica $[27,28]$. Among the analyzed twenty-seven extract samples, the highest phenolic content was found in Jonathan stem bark extract whereas the lowest content was reported in Golden peel Jumla. Our study revealed almost a similar amount of phenolic content in fruit extract in comparison to the previous study [29-31]. Flavonoids are the most diverse and widespread group of natural phenolic compounds. Hydroxyl position in the flavonoid molecule determines antioxidant properties and it depends on the ability to donate hydrogen or electron to a free radical [32]. Among the investigated plant extracts, the highest flavonoid content was found in Chocolate stem bark extract of the Jumla whereas the lowest content was detected in Golden peel Jumla. In this study, the total flavonoid content of fruit peel extract was comparable to the previous study [33]. The presence of major chemicals such as procyanidin, anthocyanins, quercetin glycosides, and cyaniding glycosides in the peels is responsible for higher flavonoid content [34]. Among all the analyzed sample extracts, the stem bark contains higher flavonoid and polyphenol content than other plant parts and the result was reported for the first time.

The present study showed that the Royal Mustang pulp contains highest and Golden Jumla pulp has lowest carbohydrate content. The experiment also showed that higher carbohydrate content was present in peel and pulp compared to leaf and bark extracts. The study on carbohydrate content in $M$. domestica of Nepalese origin has not been reported before. Free radical scavengers such as polyphenol, flavonoids, and phenolic compounds which are derived from the plants are responsible for antioxidant activity and protect us from different life-threatening diseases [35]. In the present study, the antioxidant activity was performed by DPPH radical scavenging assay. Among twenty-seven different extracts, the stem bark extract of Jonathan Jumla, 
TABLE 7: Recovery data of spiked standard to the M. domestica extract.

\begin{tabular}{|c|c|c|c|c|c|}
\hline Standard & Original $(\mu \mathrm{g} / \mathrm{mL})$ & Spiked $(\mu \mathrm{g} / \mathrm{mL})$ & Measured $(\mu \mathrm{g} / \mathrm{mL})$ & Recovery (\%) & RSD (\%) \\
\hline \multirow{3}{*}{ Quercetin } & \multirow{3}{*}{21.11} & 250 & $270.96 \pm 0.09$ & 99.29 & 0.03 \\
\hline & & 125 & $145.53 \pm 0.22$ & 97.27 & 0.16 \\
\hline & & 62.5 & $82.91 \pm 0.02$ & 96.67 & 0.03 \\
\hline \multirow{3}{*}{ Rutin } & \multirow{3}{*}{47.8} & 250 & $299.18 \pm 0.29$ & 102.89 & 0.10 \\
\hline & & 125 & $172.66 \pm 0.92$ & 99.70 & 0.53 \\
\hline & & 62.5 & $108.71 \pm 0.34$ & 96.67 & 0.31 \\
\hline
\end{tabular}

Note. All the tests were done in triplicate.

Table 8: Total rutin and quercetin content of peel, leaf, and bark of different $M$. domestica cultivars.

\begin{tabular}{|c|c|c|c|c|c|c|}
\hline \multirow{2}{*}{ Sample } & \multicolumn{2}{|c|}{ Peel (mg/100 g dry wt.) } & \multicolumn{2}{|c|}{ Leaf (mg/100 g dry wt.) } & \multicolumn{2}{|c|}{ Bark (mg/100 g dry wt.) } \\
\hline & Rutin & Quercetin & Rutin & Quercetin & Rutin & Quercetin \\
\hline Red Jumla & $3.69 \pm 0.34_{\mathrm{a}}^{\mathrm{a}}$ & $2.96 \pm 0.13_{\mathrm{a}}^{\mathrm{a}}$ & $53.21 \pm 1.82^{\mathrm{a}}{ }_{\mathrm{b}}$ & $20.75 \pm 0.44_{b}^{\mathrm{a}}$ & $289.24 \pm 3.13^{\mathrm{a}}{ }_{\mathrm{c}}$ & $72.93 \pm 1.33^{\mathrm{a}}{ }_{\mathrm{c}}$ \\
\hline Royal Jumla & $5.28 \pm 0.78^{\mathrm{a}}{ }_{\mathrm{a}}$ & $5.30 \pm 0.67_{\mathrm{a}}^{\mathrm{b}}$ & $32.29 \pm 1.14_{\mathrm{b}}^{\mathrm{b}}$ & $12.16 \pm 0.49^{\mathrm{b}}{ }_{\mathrm{b}}$ & $182.10 \pm 2.53^{\mathrm{b}}{ }_{\mathrm{c}}^{\mathrm{c}}$ & $136.64 \pm 0.85^{\mathrm{b}}$ \\
\hline Golden Jumla & $5.40 \pm 0.9^{\mathrm{a}}{ }_{\mathrm{a}}$ & $3.76 \pm 0.54^{\mathrm{ab}}{ }_{\mathrm{a}}$ & $47.80 \pm 1.43^{\mathrm{a}}{ }_{\mathrm{b}}$ & $21.11 \pm 0.58^{\mathrm{a}}{ }_{\mathrm{b}}$ & $166.28 \pm 1.34_{c}^{c}$ & $133.91 \pm 0.79^{\mathrm{bc}}$ \\
\hline Jonathan Jumla & $13.10 \pm 0.54_{\mathrm{a}}^{\mathrm{b}}$ & $8.98 \pm 0.23_{\mathrm{a}}^{\mathrm{c}}$ & $48.84 \pm 2.01_{\mathrm{b}}^{\mathrm{a}}$ & $10.25 \pm 0.72^{\mathrm{bc}}{ }_{\mathrm{a}}$ & $374.50 \pm 2.35^{\mathrm{d}}{ }_{c}^{\mathrm{c}}$ & $115.14 \pm 0.64_{c}^{\mathrm{d}}$ \\
\hline Chocolate Jumla & $5.24 \pm 0.98_{\mathrm{a}}^{\mathrm{a}}$ & $5.68 \pm 0.33^{\text {bd }}$ & $52.89 \pm 2.57^{\mathrm{a}}{ }_{\mathrm{b}}$ & $11.33 \pm 0.98^{\mathrm{bcd}}{ }_{\mathrm{b}}$ & $262.62 \pm 2.07^{\mathrm{e}}{ }_{c}^{\mathrm{c}}$ & $171.05 \pm 0.95^{\mathrm{e}}$ \\
\hline Red Mustang & $16.30 \pm 2.12^{\mathrm{bc}}{ }_{a}$ & $6.33 \pm 0.75^{\mathrm{be}}{ }_{\mathrm{a}}^{\mathrm{a}}$ & $67.56 \pm 1.12^{\mathrm{c}}{ }_{\mathrm{b}}$ & $11.33 \pm 0.34^{\text {bcde }}$ & $122.92 \pm 1.94_{c}^{\mathrm{f}}$ & $77.63 \pm 1.79^{\mathrm{f}}{ }_{\mathrm{c}}^{\mathrm{c}}$ \\
\hline Royal Mustang & $12.68 \pm 1.59^{\text {bcd }}$ & $9.68 \pm 0.36^{\mathrm{cf}_{\mathrm{a}}^{\mathrm{a}}}$ & $80.23 \pm 0.88_{b}^{\mathrm{d}}$ & $13.75 \pm 0.46^{\mathrm{bf}}{ }_{\mathrm{b}}$ & $63.85 \pm 1.91_{\mathrm{c}}^{\mathrm{g}}$ & $56.47 \pm 1.13^{\mathrm{g}}{ }_{\mathrm{c}}$ \\
\hline Golden Mustang & $11.57 \pm 0.79^{\text {bde }^{a}}$ & $11.16 \pm 0.99^{\mathrm{fg}} \mathrm{a}$ & $106.99 \pm 1.32^{\mathrm{e}} \mathrm{b}$ & $9.33 \pm 0.84^{\mathrm{cdeg}}$ & $185.41 \pm 0.95^{\mathrm{bh}}{ }_{\mathrm{c}}$ & $113.19 \pm 0.97^{\mathrm{dh}}$ \\
\hline Richard Mustang & $3.59 \pm 1.34_{\mathrm{a}}^{\mathrm{a}}$ & $2.66 \pm 0.77_{\mathrm{a}}^{\mathrm{a}}$ & $69.03 \pm 2.22_{\mathrm{b}}^{\mathrm{cf}}$ & $13.11 \pm 0.54^{\text {bdefh }}{ }_{b}$ & $103.93 \pm 2.75^{\mathrm{i}}{ }_{\mathrm{c}}$ & $72.72 \pm 0.06^{\mathrm{a}}{ }_{\mathrm{c}}$ \\
\hline
\end{tabular}

Note. All the tests were done in triplicate. Different superscript letters within the same column indicate significant differences $(P<0.05)$ among cultivars. Different subscript letters within the same row indicate significant differences $(P<0.05)$ between peel, leaf, and bark.

TABLE 9: Total quercetin content in peel, leaf, and stem bark extract of the $M$. domestica samples after acid hydrolysis.

\begin{tabular}{|c|c|c|c|c|}
\hline \multirow{2}{*}{ Location } & \multirow{2}{*}{ Varieties } & \multicolumn{3}{|c|}{ Total quercetin content (mg/100g dry extract weight) } \\
\hline & & Peel & Leaf & Stem bark \\
\hline \multirow{5}{*}{ Jumla } & Red & $96.37 \pm 33.33^{\mathrm{a}}$ a & $1542.21 \pm 46.8^{\mathrm{a}}{ }_{\mathrm{b}}$ & $5753.53 \pm 31.33^{\mathrm{a}}{ }_{\mathrm{c}}$ \\
\hline & Royal & $153.97 \pm 18.86^{a}{ }_{a}^{a}$ & $2145.39 \pm 19.23^{\mathrm{b}}{ }_{\mathrm{b}}$ & $7445.32 \pm 29.25^{\mathrm{b}}{ }_{c}$ \\
\hline & Golden & $127.22 \pm 25.06^{\mathrm{a}}{ }_{\mathrm{a}}$ & $2346.33 \pm 55.89^{\mathrm{c}}{ }_{\mathrm{b}}$ & $5168.99 \pm 28.76^{\mathrm{c}}{ }_{\mathrm{c}}$ \\
\hline & Jonathan & $259.88 \pm 23.09^{\mathrm{b}_{\mathrm{a}}}$ & $3841.14 \pm 38.9^{\mathrm{d}}{ }_{\mathrm{b}}^{\mathrm{b}}$ & $6053.64 \pm 50.04^{\mathrm{d}}{ }_{c}$ \\
\hline & Chocolate & $150.74 \pm 20.99^{\mathrm{a}}{ }_{\mathrm{a}}$ & $2010.17 \pm 35.76_{\mathrm{b}}^{\mathrm{e}}$ & $6166.28 \pm 53.08^{\mathrm{de}_{c}}$ \\
\hline \multirow{4}{*}{ Mustang } & Red & $449.07 \pm 21.49^{c}$ & $1330.31 \pm 43.87_{b}^{\mathrm{f}}$ & $3033.15 \pm 45.94_{c}^{\mathrm{f}}$ \\
\hline & Royal & $307.79 \pm 30.46^{\text {bd }}$ & $1505.58 \pm 46.95^{\mathrm{a}}{ }_{\mathrm{b}}$ & $3235.75 \pm 60.5^{\mathrm{g}}{ }_{\mathrm{c}}$ \\
\hline & Golden & $309.78 \pm 35.01^{\text {bde }^{\mathrm{a}}}$ & $2587.30 \pm 32.51_{\mathrm{b}}^{\mathrm{g}}$ & $4350.61 \pm 30.06^{\mathrm{h}}{ }_{\mathrm{c}}$ \\
\hline & Richard & $80.84 \pm 19.65^{\mathrm{a}}{ }_{\mathrm{a}}$ & $2290.14 \pm 33.37^{\mathrm{gh}} \mathrm{b}$ & $3741.00 \pm 39.44_{c}^{\mathrm{i}}$ \\
\hline
\end{tabular}

Note. All the tests were done in triplicate. Different superscript letters within the same column indicate significant differences $(P<0.05)$ among cultivars. Different subscript letters within the same row indicate significant differences $(P<0.05)$ between peel, leaf, and bark.

Chocolate Jumla, and leaf extract of Red Jumla showed the most significant radical scavenging activity with $\mathrm{IC}_{50}$ value of $13.003 \mu \mathrm{g} / \mathrm{mL}, 14.605 \mu \mathrm{g} / \mathrm{mL}$, and $15.49 \mu \mathrm{g} / \mathrm{mL}$, respectively. Higher value of total phenol and flavonoid content might be responsible for potent antioxidant activity of these extracts. Antioxidant capacities of the peel extracts in this study are comparable to a previous study [30, 31].

For the quantitative analysis of total quercetin and rutin content, the HPLC method was optimized for simultaneous determination of quercetin and rutin in peel, leaf, and steam bark extract of $M$. domestica. The method was validated for various parameters like linearity, LODs, LOQs, precision, and accuracy. All these parameters were found to be within the range of $\mathrm{ICH}$ guidelines. The quercetin and rutin contents in different plants parts were found in increasing order as peel $<$ leaf $<$ stem bark. The total concentrations of quercetin and rutin were found to be varied among the cultivars. The highest amount of quercetin and rutin was quantified in Royal Jumla stem bark extract. The variation in genetic makeup, cultivation condition, phases of growth, soil condition, and fertilization condition may contribute to the difference in the quantitative composition of phytochemical among the cultivars. Moreover, differences in weather condition and meteorological and geographical condition might also be a possible factor [36-38]. Quercetin can be found freely as well in glycosidic form [13]. Acid hydrolysis 
was carried out in this study for the conversion of the glycosidic form of quercetin into aglycone form. Hydrochloric acid was chosen for this purpose as it is efficient as compared to sulphuric acid [12]. The total amount of quercetin was increased in all the extracts after the acid hydrolysis. Quercetin content in peel extract was reported to increase by about 12 times after acid hydrolysis, which was also supported by literature [12]. Interestingly, while comparing the apple cultivars of two different climates, the experiment showed that fruits of Mustang were better as compared to fruits of Jumla but leaf and stem bark of the Jumla were found to be better than the Mustang.

\section{Conclusion}

The present study showed that methanolic extract of peel, leaf, and stem bark of $M$. domestica exhibited potent antioxidant activity due to the presence of polyphenols, flavonoids, and other various phytochemicals. Peel and pulp contain higher carbohydrate content and are responsible for nutritional value along with pleasant taste. The study provides strong evidence about the presence of high quercetin and rutin content in stem bark relative to peel and leaf of $M$. domestica of Nepalese origin. Moreover, we can conclude that the content of quercetin and rutin may vary among the different cultivars and different plant parts and also influenced by the geographical locations.

\section{Data Availability}

All the data used to support the result of this research are available from the authors Tripathi J. and Tripathi M. upon request.

\section{Disclosure}

This research was performed as part of the partial fulfillment of academic degree at Pokhara University.

\section{Conflicts of Interest}

The authors declare no conflicts of interest.

\section{Authors' Contributions}

Jitendra Pandey, Tonking Bastola, Julu Tripathi, Milu Tripathi, and Rabindra Kumar Rokaya contributed equally to this work.

\section{Acknowledgments}

The authors are very much grateful to the Department of Pharmacy, Pokhara University, for providing all the technical support. The authors would like to acknowledge sincerely Mr. Bal Krishna Adhikari, Botanist of Temperate Horticulture Development Center, Marpha, Mustang, and Mr. Kalam Bahadur Khatri, JTA, Jumla, for providing plant samples.

\section{References}

[1] V. A. A. Sluis, "A chain analysis of the production of "healthy" apple juice. the case of polyphenolic anti-oxidants" $\mathrm{PhD}$ Thesis, Wageningen University, Wageningen, The Netherlands, 2005.

[2] J. Moskovitz, M. B. Yim, and P. B. Chock, "Free radicals and disease," Archives of Biochemistry and Biophysics, vol. 397, no. 2, pp. 354-359, 2002.

[3] A. Carr and B. Frei, "The role of natural antioxidants in preserving the biological activity of endothelium-derived nitric oxide," Free Radical Biology and Medicine, vol. 28, no. 12, pp. 1806-1814, 2000.

[4] V. Patel, R. Kaswal, M. Chakraborty, and J. V. Kamath, "Phytochemical and pharmacological profile of Malus domestica: an overview," International Journal of Current Biomedical and Pharmaceutical Research, vol. 2, no. 2, pp. 334-338, 2012.

[5] J. P. Robinson, S. A. Harris, and B. E. Juniper, "Taxonomy of the genus Malus mill. (Rosaceae) with emphasis on the cultivated apple, Malus domestica Borkh," Plant Systematics and Evolution, vol. 226, no. 1-2, pp. 35-58, 2001.

[6] J. Boyer and R. H. Liu, "Apple phytochemicals and their health benefits,” Nutrition Journal, vol. 3, p. 5, 2004.

[7] D. R. Lauren, W. A. Smith, A. Adaim et al., "Chemical composition andin vitroanti-inflammatory activity of apple phenolic extracts and of their sub-fractions," International Journal of Food Sciences and Nutrition, vol. 60, no. 7, pp. 188-205, 2009.

[8] Y. Hamauzu, M. Irie, M. Kondo, and T. Fujita, “Antiulcerative properties of crude polyphenols and juice of apple, and Chinese quince extracts," Food Chemistry, vol. 108, no. 2, pp. 488-495, 2008.

[9] H. J. Heo, D. O. Kim, S. J. Choi, D. H. Shin, and C. Y. Lee, "Apple phenolics protect in vitro oxidative stress-induced neuronal cell death,” Journal of Food Sciences, vol. 69, no. 9, pp. 357-360, 2004.

[10] J. V. Formica and W. Regelson, "Review of the biology of quercetin and related bioflavonoids," Food and Chemical Toxicology, vol. 33, no. 12, pp. 1061-1080, 1995.

[11] J. Markowski and W. Płocharski, "Determination of phenolic compounds in apples and processed apple products," Journal of Fruit and Ornamental Plant Research, vol. 14, no. 2, pp. 133-142, 2006.

[12] A. Wach, K. Pyrzyńska, and M. Biesaga, "Quercetin content in some food and herbal samples," Food Chemistry, vol. 100, no. 2, pp. 699-704, 2007.

[13] R. Tsao, R. Yang, J. C. Young, and H. Zhu, "Polyphenolic profiles in eight apple cultivars using high-performance liquid chromatography (HPLC)," Journal of Agricultural and Food Chemistry, vol. 51, no. 21, pp. 6347-6353, 2003.

[14] D. H. Gracelin, A. Britto, and B. Kumar, "Qualitative and quantitative analysis of phytochemicals in five Pteris species," International Journal of Pharmacy and Pharmaceutical Sciences, vol. 5, no. 1, pp. 105-107, 2013.

[15] W. C. Evans, Trease and Evans' Pharmacognosy International Edition E-Book, Elsevier Health Sciences, Amsterdam, The Netharlands, 2009.

[16] G. A. Ayoola, H. A. B. Coker, S. A. Adesegun et al., "Phytochemical screening and antioxidant activities of some selected medicinal plants used for malaria therapy in southwestern Nigeria," Tropical Journal of Pharmaceutical Research, vol. 7, no. 3, pp. 1019-1024, 2008.

[17] J. Beertoncelj, U. Doberšek, M. Jamnik, and T. Golob, "Evaluation of the phenolic content, antioxidant activity and 
colour of Slovenian honey," Food Chemistry, vol. 105, no. 2, pp. 822-828, 2007.

[18] E. Verzelloni, D. Tagliazucchi, and A. Conte, "Relationship between the antioxidant properties and the phenolic and flavonoid content in traditional balsamic vinegar," Food Chemistry, vol. 105, no. 2, pp. 564-571, 2007.

[19] A. A. Albalasmeh, A. A. Berhe, and T. A. Ghezzehei, "A new method for rapid determination of carbohydrate and total carbon concentrations using UV spectrophotometry," Carbohydrate Polymers, vol. 97, no. 2, pp. 253-261, 2013.

[20] A. Ferreira, C. Proença, M. L. M. Serralheiro, and M. E. M. Araújo, "The in vitro screening for acetylcholinesterase inhibition and antioxidant activity of medicinal plants from Portugal," Journal of Ethnopharmacology, vol. 108, no. 1, pp. 31-37, 2006.

[21] D. Shrestha, J. Pandey, C. Gyawali et al., "Study of in vitro anti-oxidant and anti-diabetic activity by Mussaenda macrophylla root extracts," International Journal of Current Pharmaceutical Research, vol. 12, no. 4, pp. 70-74, 2020.

[22] J. Wang, L. Zhao, G. Sun et al., "A comparison of acidic and enzymatic hydrolysis of rutin," African Journal of Biotechnology, vol. 10, no. 8, pp. 1460-1466, 2011.

[23] International conference of harmonization Q2B, Validation of Analytical Procedures-Methodology, pp. 27463-27467, US FDA Federal Register, White Oak, MD, USA, 1997.

[24] A. Poudel, J. Pandey, and H.-K. Lee, "Geographical discrimination in curcuminoids content of turmeric assessed by rapid UPLC-DAD validated analytical method," Molecules, vol. 24, no. 9, p. 1805, 2019.

[25] N. Savithramma, M. L. Rao, and D. Suhrulatha, "Screening of medicinal plants for secondary metabolites," Middle East Journal of Scientific Research, vol. 8, no. 3, pp. 579-584, 2011.

[26] D. Lin, M. Xiao, J. Zhao et al., "An overview of plant phenolic compounds and their importance in human nutrition and management of type 2 diabetes," Molecules, vol. 21, no. 10, p. $1374,2016$.

[27] M. V. Eberhardt, C. Y. Lee, and R. H. Liu, "Antioxidant activity of fresh apples," Nature, vol. 405, no. 6789, pp. 903-904, 2000.

[28] K. W. Lee, Y. J. Kim, D.-O. Kim, H. J. Lee, and C. Y. Lee, "Major phenolics in apple and their contribution to the total antioxidant capacity," Journal of Agricultural and Food Chemistry, vol. 51, no. 22, pp. 6516-6520, 2003.

[29] M. A. Ali, L. I. Devi, V. Nayan, K. V. Chanu, and L. Ralte, "Anti-oxidant activity of fruits available in Aizawl market of Mizoram India," International Journal of Biological and Pharmaceutical Research, vol. 1, no. 2, pp. 76-81, 2010.

[30] B. D’Abrosca, S. Pacifico, G. Cefarelli, C. Mastellone, and A. Fiorentino, "Limoncella" apple, an Italian apple cultivar: phenolic and flavonoid contents and antioxidant activity," Food Chemistry, vol. 104, no. 4, pp. 1333-1337, 2007.

[31] M. Manzoor, F. Anwar, N. Saari, and M. Ashraf, "Variations of antioxidant characteristics and mineral contents in pulp and peel of different apple (Malus domestica Borkh.) cultivars from Pakistan," Molecules, vol. 17, no. 1, pp. 390-407, 2012.

[32] M. Liaudanskas, P. Viškelis, R. Raudonis, D. Kviklys, N. Uselis, and V. Janulis, "Phenolic composition and antioxidant activity of Malus domestica Leaves," The Scientific World Journal, vol. 2014, pp. 1-11, 2014.

[33] M. Iqbal, M. Sharma, R. F. Ali, M. Yousuf, and A. Hussain, "In vitro antioxidant activity and spectrophotometric quantification of total phenolic and flavonoid contents of Malus domestica," World Journal of Pharmaceutical Research, vol. 3, no. 1, pp. 452-471, 2013.
[34] K. Wolfe, X. Wu, and R. H. Liu, "Antioxidant activity of apple peels," Journal of Agricultural and Food Chemistry, vol. 51, no. 3, pp. 609-614, 2003.

[35] H. Amiri, "Volatile constituents and antioxidant activity of flowers, stems and leaves of Nasturtium officinale R. Br," Natural Product Research, vol. 26, no. 2, pp. 109-115, 2012.

[36] A. B. Bentz, "A review of quercetin: chemistry, anti-oxidant properties, and bioavailability," Journal of Young Investigators, vol. 19, pp. 1-14, 2009.

[37] E. Nemeth, "Essential oil composition of species in the Genus Achillea," Journal of Essential Oil Research, vol. 17, no. 5, pp. 501-512, 2005.

[38] O. Gudaityte and P. R. Venskutonis, "Chemotypes of Achillea millefolium transferred from 14 different locations in Lithuania to the controlled environment," Biochemical Systematics and Ecology, vol. 35, no. 9, pp. 582-592, 2007. 